\title{
Effect of Metformin Pretreatment on Serum Adropin Level in Rats with Adrenalin-Induced Acute Myocardial Infarction
}

\author{
EBTESAM M. IBRAHIM, M.D.*; ALAA I. ALI, M.D.** and MAHMOUD M.A. ABULMEATY, M.D.* \\ The Department of Physiology* and Pharmacology**, Faculty of Medicine, Zagazig University, Egypt
}

\begin{abstract}
Background: Beside adropin's role in energy homeostasis and insulin sensitivity, it is also incriminated in myocardia ischemia. Level of adropin during myocardial infarction (MI) and the effect of metformin pretreatment on serum adropin level in rat models of MI is underinvestigated.
\end{abstract}

Aim of Study: This study investigated the level of adropin in MI and the possible involvement of adropin and endothelial nitric oxide synthase enzyme activity (eNOS) in the cardioprotective effect of metformin during acute myocardial ischemia.

Material and Methods: A total of forty adult male albino rats weighing $185-220 \mathrm{~g}$ were divided equally into four groups Group I: Normal control group. Group II: MI group, which was induced by subcutaneous injection of adrenalin $(2 \mathrm{mg} / \mathrm{kg})$ in two doses 24 hours apart. Group III: Normal rats which were treated with oral metformin via a feeding tube in a dose of $300 \mathrm{mg} / \mathrm{kg}$ for 2 weeks. Group IV: Rats with adrenalininduced MI and pretreated with oral metformin in the same dose and duration before induction of MI on the 13 th and $14^{\text {th }}$ days of the study. Serum adropin and eNOS were measured, in addition to cardiac troponin I, Creatine Kinase isoenzyme (CK-MB), and C-reactive protein (CRP). Sections from the heart was stained with Masson's trichrome stain and examined to quantify the degree of ischemic injury at the tissue level.

Results: In MI group, both serum adropin level and the eNOS were significantly increased with significant positive correlation between adropin and troponin I, CK-MB, and eNOS in the same group $(r=0.857,0.97 \& 0.845$, respectively, $p<0.05$ ). However, Metformin pretreatment in group IV, produced significant reduction in the level of adropin accompanied by significant increase in levels of eNOS enzyme activity in comparison to rats with untreated MI. Additionally histological examination, showed reduction of the inflammatory cell infiltration, myocardial fibrosis and necrosis. Moreover, there was a positive correlation between adropin and eNOS in the same group $(r=0.682, p<0.05)$.

Conclusion: Adropin and eNOS enzyme play a vital role in the pathophysiology of acute myocardial infarction. In

Correspondence to: Dr. Mahmoud M.A. Abulmeaty, E-mail: prof.i.mohammad@gmail.com. addition, the cardioprotective effect of metformin pretreatment in this condition depends on enhancing the activity of eNOS enzyme independent on adropin level.

Key Words: Adropin-eNOS-Metformin-MI-Rat model.

\section{Introduction}

ADROPIN is a recently discovered peptide hormone, which plays a significant role in carbohydrate, lipid and protein metabolism [1]. Adropin is encoded by the Energy Homeostasis Associated gene (gene symbol: Enho). The expression of Enho gene in different tissues mainly the liver and the brain depends upon the energy status and the contents of diet [2]. Adropin has essential participation in the maintenance of energy homeostasis and sensitivity of different cells to insulin and also during the development and progression of atherogenesis [3]. It is a new contributing factor in cardiovascular diseases especially ischemic injuries of the heart. However, adropin level in conditions of myocardial ischemia showed some controversy which makes the potential role of adropin as a biomarker for diagnosis and follow-up in certain cardiovascular disorders such as heart failure and ischemic heart diseases a great area of interest [4] Some reports claimed that serum adropin level is elevated in acute myocardial infarction (MI) [5] On the other hand, Celik et al., [6] reported a possible correlation between low serum adropin level and ischemic heart diseases in some cardiac patients. Recent reports expressed the potential role of adropin at the endothelial cells that is mostly mediated through excessive expression of endothelial nitric oxide synthase (eNOS) enzyme via the vascular endothelial growth factor receptor 2 (VEGFR2)-phosphatidylinositol 3-kinase-Akt and VEGFR2-extracellular signal regulated kinase 1/2 pathways $[4,7]$. Therefore, adropin might be involved in protective mechanisms against ischemia/ reperfusion models. 
On the other hand, metformin plays an essential role in treatment of diabetes mellitus and in prevention of its complication especially the cardiovascular complications [8]. Interestingly, recent reports revealed the cardioprotective effects of metformin against MI even in non-diabetic cases [9].The pharmacological actions of metformin mediated intracellularly through the activation of adenosine monophosphate (AMP)-activated protein kinase (AMPK) [10]. The cellular level of AMPK elevated in response to some metabolic changes e.g. exercise, ischemia, oxidative stress and hypoglycemia [11]. In addition to the metabolic action of activated AMPK in the form of fatty acids oxidation, promotion of glucose uptake and acceleration of glycolysis, this enzyme also promotes the phosphorylation and activity of eNOS [12].

Recently the relation between adropin level and the expression of eNOS was studied. It was claimed that, adropin favors upregulation of eNOS expression through the VEGFR2-phosphatidylinositol 3-kinase-Akt and VEGFR2-extracellular signal regulated kinase $1 / 2$ pathways [13]

So the present work aimed to investigate serum level of adropin and eNOS and explore their possible involvement in the cardioprotective effect of metformin in experimentally-induced acute MI in adult male albino rats.

\section{Patients and Methods}

\section{Animals:}

In the period from 15 th of October 2017 to 15 th of January 2018, the study was performed in the animal house of Faculty of Medicine, Zagazig University, and involved a total of forty adult male albino rats weighing $185-220 \mathrm{~g}$ were obtained from the experimental animal services house of the Faculty of Pharmacy, Zagazig University. Rats were kept for acclimatization in clean cages in groups of five for one week. Rats were fed the normal balanced rodent formula with water ad libitum. Room temperature was about $25^{\circ} \mathrm{C}$ and a $12 \mathrm{~h} \mathrm{light/dark} \mathrm{cycle.} \mathrm{The} \mathrm{animal} \mathrm{experiments} \mathrm{were}$ approved by the Institutional Research Board, and ethics committee, Faculty of Medicine, Zagazig University.

Rats were divided into four groups (10 rats/ group). Group I: Normal control group. Group II: Acute MI group, which was induced by subcutaneous injection of adrenalin $(2 \mathrm{mg} / \mathrm{kg})$ in two doses with an interval of 24 hours on day 13 and 14 of the study [14] . Group III: Normal rats which were treated with oral metformin (Minapharm Co.
Egypt). Group IV: Metformin pretreated acute MI group.

Metformin was administered orally via a feeding tube in a dose of $300 \mathrm{mg} / \mathrm{kg}$ for 2 weeks from the start of the study in both group III and IV, while animals in group I and II was treated with oral saline for the same duration [15].

\section{Blood sampling:}

At the end of the study, and after overnight fasting, blood sample was collected via cardiac puncture from the rats while under anesthesia (Ether anasthesia in a vaporizer chamber), followed immediately by decapitation as a humane method of euthanasia. Blood samples were collected in tubes, centrifuged for $15 \mathrm{~min}$ at $3000 \mathrm{rpm}$. The separated serum was stored at $20^{\circ} \mathrm{C}$ until the time of measurement.

\section{Biochemical analysis:}

The serum level of adropin was measured by ELISA kits (Sun Red Biotechnology, ChinaCatalogue No 201-11-3361) [16]. Serum cardiac troponin I was measured by enzyme immunoassay (OPUS, Marburg CO, Germany), and Creatine Kinase isoenzyme (CK-MB) was measured with an autoanalyzer (Hitachi 917, Roche Co, Germany) [17]. C-reactive protein (CRP) was assayed by rate nephelometry technique (Behring NA latex CRP; Behring Co, Germany) [18]. Determination of nitric oxide synthase (NOS) enzymatic activity was done by colorimetric method [19] using commercial kits (BioVision Co USA-Catalogue No K205).

\section{Histopathology:}

Immediately after decapitation, heart was excised. Hearts were rapidly opened and washed with saline then fixed in $10 \%$ formalin solution. The heart tissues were embedded in paraffin, sectioned at 5 microtome, and stained with Masson's trichrome stain [20]. Stained sections were examined under light microscope (400x) equipped with digital camera.

\section{Statistical analysis:}

Study results were presented as mean \pm SD and SPSS 23 was used for futher analysis (SPSS Inc. Chicago, IL, USA). One way Analysis of variance (ANOVA) was used followed by a post hoc test (student-least significant differences, LSD test) to compare statistical differences between groups. Pearson's correlation was done to detect associations between the studied parameters. $p$-values $<0.05$ was considered to be significant. 


\section{Results}

Serum parameters in adrenalin-induced MI:

As shown in Table (1), serum adropin level as well as the eNOS enzyme activity was significantly increased in adrenalin-induced MI group in comparison to control group.

In addition, levels of eNOS showed significant positive correlation with adropin levels in the same group $(r=0.845, p<0.05)$ (Table 2). Moreover, the levels of cardiac enzymes, Troponin I and CK-MB, as well as CRP showed significant high levels in induced-MI group versus control (Table 1).

\section{Effects of metformin pretreatment:}

Rats of group IV showed significant lower levels of Adropin versus rats with untreated MI (Table 1), however, it was significantly increased when compared to group I and III.

Regarding eNOS enzyme activity, Metformin treatment significantly increased its activity in both group III and IV in comparison of group I (Table 1). Pearson test showed a positive correlation between Adropin and eNOS in rats of group IV.

Table (1): Mean values of serum parameters in all studied groups.

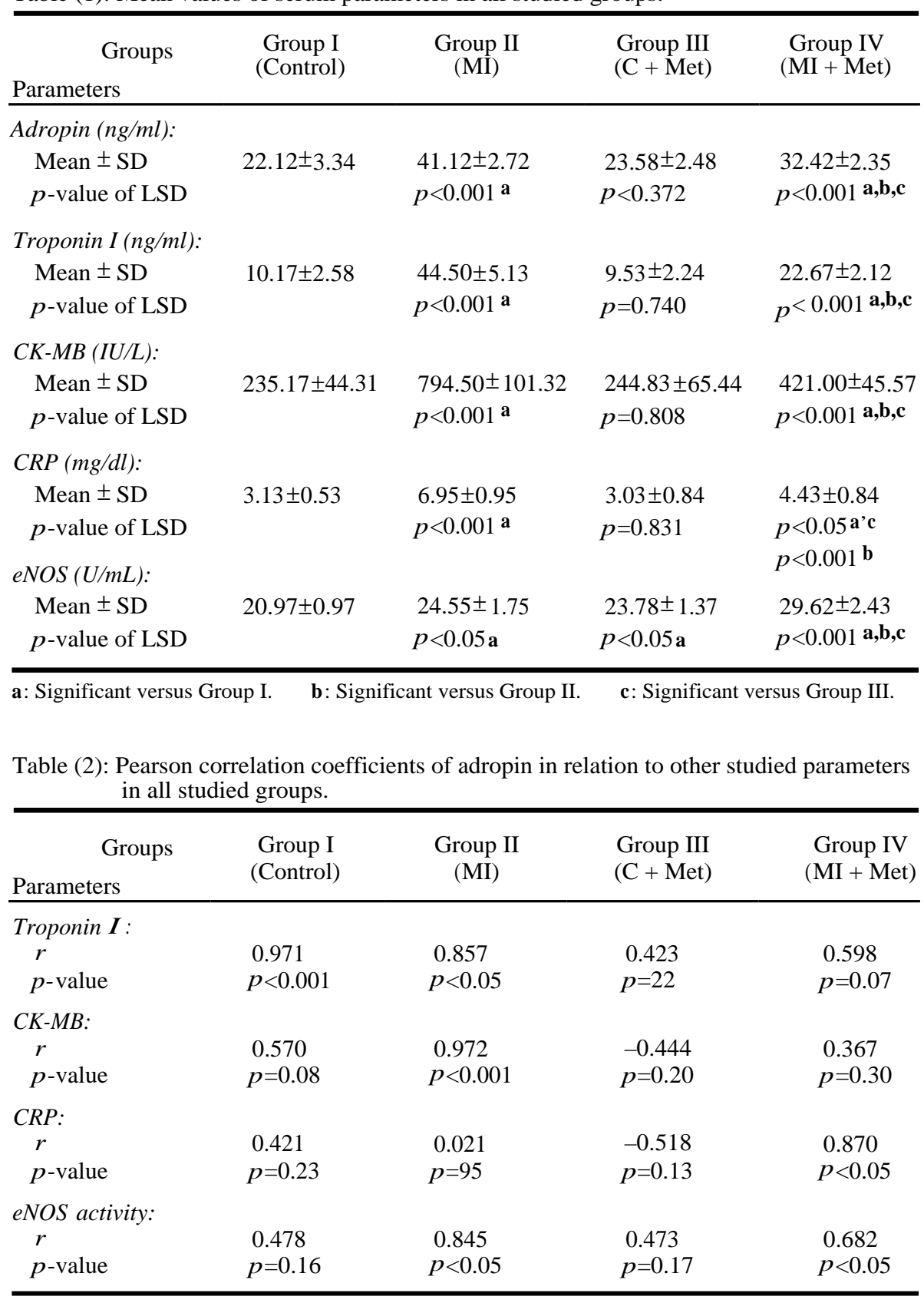




\section{Histopathological changes:}

As demonstrated in Fig. (1), sections of myocardial tissues in group (I) and group (III) showed regularly arranged muscle fibers with no evidence of necrotic areas or fibrosis, while in MI (group
II), there are widespread myocardial necrosis, myocardial hypertrophy, and widespread homogenous fibrous tissue (arrows). However in metformin pretreated MI rats (group IV) they showed apparent reduction of the inflammatory cell infiltration, myocardial fibrosis and necrosis.
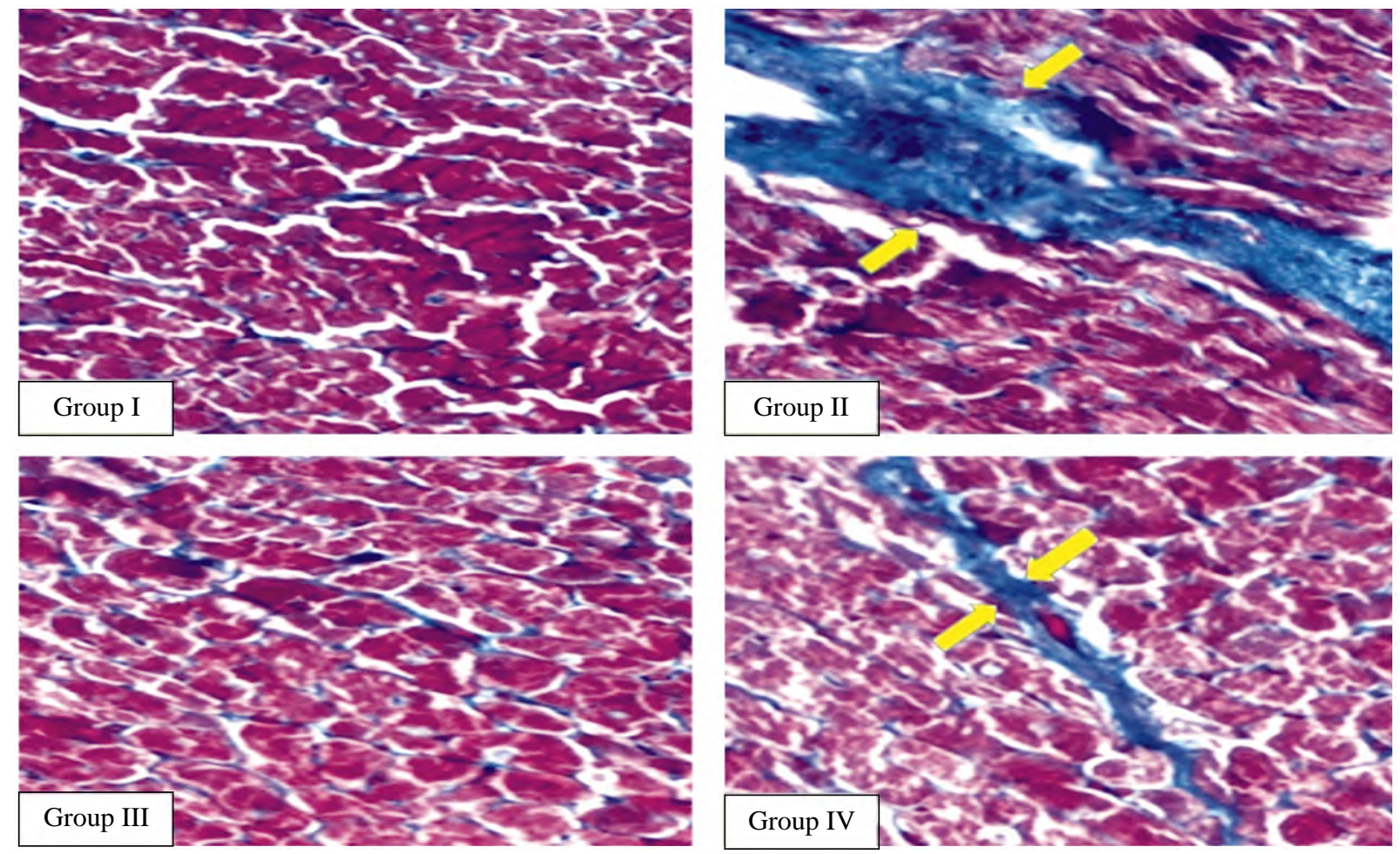

Fig. (1): Histopathological changes in the study groups (Masson's trichrome staining x400) arrow showing the area of infarction with inflammatory cell infiltration, myocardial fibrosis and necrosis.

\section{Discussion}

Metformin as an euglycemic medication is clinically used since more than 60 years, however, its non-diabetic uses especially as a cardioprotective agent is a hot area of research [21]. Reports pointed to the role of metformin in cardiovascular diseases through potential mechanisms independent on its anti-diabetic effects. These reports reveled the protective effect of metformin against MI via its ability to decrease the infarction size and to improve cardiac functions in animal models of MI [22]. The biochemical and histological results of the present study coincide with these findings. The results of the present study showed significant reduction of troponin I, CK-MB and CRP in MImetformin-treated group in comparison to control group, moreover the histological examination of cardiac tissues emphasized the protective effect of metformin as it attenuated the extent of myocardial tissue injury in the form of reducing the inflammatory cell infiltration, myocardial fibrosis and necrosis.

Regardless the therapeutic use of metformin, AMPKK plays the essential role in its intracellular effects $[\mathbf{1 0 , 2 3}]$. The activated AMPKK has wellknown metabolic effects which favor the glucose utilization and increase insulin sensitivity [24]. The activated AMPKK regulates many intracellular pathways. One of the most important activated intracellular pathways is that for eNOS production [12]. Results of our study showed significant elevation of eNOS level in metformin groups in comparison to other groups. Oidor-Chan et al., [15] reported that the cardioprotective effect of metformin depends upon the restoration of eNOS bioavailability in the cardiac tissues which is mediated partially through activation of PPAR- a receptors with subsequent anti-oxidant effect. In the current study the estimated serum level of eNOS showed significant elevation in all groups 
in comparison to the control group and the maximal elevation were observed in the MI-metformin treated group. It seems that the expression of eNOS is stimulated and subsequently elevated in response to ischemic injury as a compensatory mechanism [25] and the role of metformin is to enhance this compensatory mechanism in order to minimize the sequel of ischemic insult. Jones et al., [26] showed that nitric oxide which is released as a result of phosphorylation and activation of eNOS has an essential role as a cardioprotective signal molecule through its antioxidant effect, its vasodilator action, anti-platelets effect and leucocyte chemotactic role.

Beside PPAR-a receptors, there are many other metabolic signal molecules which play significant role in the pathogenesis and prognosis of ischemic heart diseases and the other cardiovascular disorders [27]. Adropin is a recently discovered protein which proved to be participated in energy balance und insulin sensitivity [3]. It is also discovered that adropin is essential to maintain the structure and function of endothelial cells [28]. It is well-known that endothelial dysfunction is an essential factor for development of coronary atherosclerosis and ischemic heart diseases [29]. Adropin maintains the vitality of endothelial cells by preserving the bioavailability of nitric oxide which is produced through eNOS. This pathway is also affected in case of metformin administration as mentioned above. Interestingly Aydin et al., [30] reported that the serum level in isoproterenol-induced $\mathrm{MI}$ in rats is elevated and they explained this finding by the release of adropin into the serum after damage of myocytes due to acute MI and the authors recommended usage of adropin as a diagnostic marker with troponin I in early detection of MI. In agreement with previous report we also found that serum level of adropin in MI-group was significantly elevated in comparison to both control group and also metformin-treated group, this elevation emphasizes both the idea of implication of adropin as a biomarker of heart diseases [3] and also the protective role of metformin against ischemic heart lesions $[\mathbf{8 , 9}$. From all previous studies and their findings, it was obvious that metformin as a commonly prescribed drug and adropin as a recent detected peptide play essential role in ischemic heart diseases and they share in increasing the production or activity of eNOS $[\mathbf{1 2}, \mathbf{2 8}]$

According to the result of current study, metformin-pretreated MI group (group IV) showed significant reduction in serum adropin level in comparison to non-treated MI group, however, metformin treatment in normal group (group III) showed non-significant elevation in serum adropin level in comparison to control group, These results elucidate that the cardioprotective role of metformin depends upon potential mechanisms rather than adropin production, although both substances favors eNOS production.

Interestingly, Lovren et al., [4] reported that Akt/protein kinase B is the main pathway by which adropin upregulates eNOS synthesis and expression. However, Calvert et al., [24] proved that metformin couldn't activate this pathway and depends mainly on AMP Kinase pathway. These findings correlate with the results of current study which showed maintained elevation in serum eNOS in metformin-treated groups although adropin levels were lower in these groups than in group II.

In conclusion, the increase in both serum adropin and eNOS enzyme activity might be involved in the pathogenesis of acute MI interestingly; metformin pretreatment has a cardioprotective role depending on enhancing production of eNOS enzyme activity independent of adropin level. Future investigations are recommended for much clarification cellular pathways of cardioprotective effects of metformin.

Acknowledgment: To Dr Hanan Lotfy, lecturer of pathology, Zagazig Univerisity, faculty of medicine, for assistance in preparation, staining and reporting of the pathology sections.

\section{References}

1- GAO S., McMILLAN R.P., ZHU Q., LOPASCHUK G.D., HULVER M.W. and BUTLER A.: Therapeutic effects of adropin on glucose tolerance and substrate utilization in diet-induced obese mice with insulin resistance. Molecular Metabolism, 4 (4): 310-324, 2015.

2- KUMAR K., JAMES L., DANIEL D., GREGORY M., ROBERT A., VLADIMIR N., KONSTANTIN G., PAMELA M., ROBERT A., MARIE T., ANTHONY W., RANDALL L., THOMAS P., JESSE Z., HEATHER A., MICHAEL D., LORA K., JACQUELINE M., and ANDREW A.: Identification of Adropin as a Secreted Factor Linking Dietary Macronutrient Intake with Energy Homeostasis and Lipid Metabolism. Cell. Metab., 8 (6): 468481,2008

3- YOSAEE S., SOLTANI S., SEKHAVATI E., and JAZAJERI S.: Adropin- A Novel Biomarker of Heart Disease: A Systematic Review Article. Iran J. Public. Health, 45 (12): 1568-1576, 2016.

4- LOVREN F., PAN Y, QUAN A., SINGH KK, SHUKLA P.C., GUPTA M., Al-OMRAN M., TEOH H. and VERMA S.: Adropin is a novel regulator of endothelial function. Circulation, 122: 185-192, 2010.

5- KULOGLU T. and AYDIN S.: Immunohistochemical expressions of adropin and inducible nitric oxide synthase in renal tissues of rats with streptozotocin-Induced exper- 
imental diabetes. Biotech. Histochem, 89 (2): 104-110, 2014.

6- CELIK A., BALIN M, KOBAT M.A., ERDEM K., BAYDAS A. and BULUT M.: Deficiency of a new protein associated with cardiac syndrome $\mathrm{X}$; called adropin. Cardiovasc Ther, 31 (3): 174-178, 2013.

7- YOLBAS S., KARA M., YILDIRIM A., GUNDOGDU B., KALAYCI M., and AYDIN S.: THU0489 Enho Gene Expression and Serum Adropin Level in Rheumatoid Arthritis and Systemic Lupus Erythematosus. Ann. Rheum. Dis., 73 (2): 352-353, 2014.

8- HEMMINGSEN B., LUND S.S., GLUUD C., VAAG A., ALMDAL T., HEMMINGSEN C. and WETTERSLEV J.: Intensive glycaemic control for patients with type 2 diabetes: Systematic review with meta-analysis and trial sequential analysis of randomised clinical trials. BMJ., 343: d6898, 2011.

9- LIVINGSTONE S.J., LEVIN D., LOOKER H.C., LINDSAY R.S., WILD S.H., JOSS N., LEESE G., LESLIE P., McCRIMMON R.J. and METCALFE W.: Estimated life expectancy in a Scottish cohort with type 1 diabetes, 2008-2010. JAMA., 313: 37-44, 2015.

10- HAWIEY S.A., GADALLA A.E., OLSEN G.S. and HARDIE D.G.: The antidiabetic drug metformin activates the AMP-activated protein kinase cascade via an adenine nucleotide-independent mechanism. Diabetes, 51: 24202425, 2002.

11- HARDIE D.G.: The AM: P-activated protein kinase pathway-new players upstream and downstream. J. Cell. Sci., 117: 5479 -5487, 2004.

12- MORROW V.A., FOUFELLE F., CONNELL J.M., PETRIE J.R., GOULD G.W. and SALT I.P.: Direct activation of AMP-activated protein kinase stimulates nitricoxide synthesis in human aortic endothelial cells. J. Biol. Chem., 278: 31629-31639, 2003.

13- VERMA S., BUCHANAN M.R. and ANDERSON T.J.: Endothelial function testing as a biomarker of vascular disease. Circulation, 108: 2054-2059, 2003.

14- AHMED A.A.M. and MASOUD R.A.: Cardioprotective potential of Basil oil and vitamin $E$ against oxidative stress in experimental myocardial infarction induced by epinephrine in rats. AAMJ, 12 (4): 15-24, 2014.

15- OIDOR-CHAN V.H., HONG E., PEREZ-SEVERIANO F., MONTES-S., TORRES-NARVAEZ J.C., VALLE= MONDRAGO N-L., GUSTAVO PASTELIN-HERNA NDEZG., and SANCHEZ-MENDOZA A.: Fenofibrate plus Metformin Produces Cardioprotection in a Type 2 Diabetes and Acute Myocardial Infarction Model. PPAR. Research, Article ID., 8237264, 14 pages, 2016.

16- YANG C., DE-MARS K.M., HAWKINS K.E. and CANDELARIO-JALIL E.: Adropin reduces paracellular permeability of rat brain endothelial cells exposed to ischemialike conditions. Peptides, 81: 29-37, 2016.

17- LARUE C., CALZOLARI C., BERTINCHANT J.P., LECLERCQ F., GROLLEAU R. and PAU B.: Cardiacspecific immuno enzymomimetic assay of troponinI in the early phase of acute myocardial infarction. Clin. Chem., 39: 972-981, 1993.

18- SHINE B., de BEER F.C. and PEPYS M.B.: Solid phase radioimmunoassays for human C-reactive protein. Clin. Chim. Acta., 117: 13-23, 1981.

19- ZHU F., XU S., ZHANG Y., CHEN F., JI J., and XIE G.: Total Glucosides of Paeony Promote Intestinal Motility in Slow Transit Constipation Rats through Amelioration of Interstitial Cells of Cajal. PLoS. ONE, 11 (8): e0160398, 2016.

20- AHMET I., TAE H.J., BRINES M., CERAMI A., LAKATTA E.G. and TALAN MI.: Chronic administration of small nonerythropoietic peptide sequence of erythropoietin effectively ameliorates the progression of postmyocardial infarction-dilated cardiomyopathy. J Pharmacol Exp Ther. 345: 446-456, 2013.

21- DAVIS B.J., XIE Z., VIOLLET B. and ZOU M.H.: Activation of the AMP-activated kinase by antidiabetes drug metformin stimulates nitric oxide synthesis in vivo by promoting the association of heat shock protein 90 and endothelial nitric oxide synthase. Diabetes, 55: 496-505, 2006.

22- KIRPICHNIKOV D., McFARLANE S.I. and SOWERS J.R.: Metformin: an update. Ann. Intern. Med., 137: 2533, 2002.

23- HAWLEY S.A., BOUDEAU J., REID J.L., MUSTARD K.J., UDD L., MAKELA T.P., ALESSI D.R. and HARDIE D.G.: Complexes between the LKB1 tumor suppressor, STRAD alpha/beta and MO25 alpha/beta are upstream kinases in the AMP-activated protein kinase cascade. J. Biol., 2 (4): 28, 2003.

24- CALVERT J.W., GUNDEWAR S., JHA S., GREER J.J., BESTERMANN W.H., TIAN R. and , LEFER D.J.: Acute Metformin Therapy Confers Cardioprotection Against Myocardial Infarction Via AMPK-eNOS-Mediated Signaling. Diabetes, 57 (3): 696-705, 2008.

25- AKOUMIANAKIS I., TARUM A. and ANTONIADES C.: Perivascular adipose tissue as a regulator of vascular disease pathogenesis: Identifying novel therapeutic targets. Br. J. Pharmacol., 174: 3411-3424, 2017.

26- JONES SP, GREER J.J., KAKKAR A.K., WARE P.D., TURNAGE R.H., HICKS M., VAN HAPEREN R., DE CROM R., KAWASHIMA S., YOKOOYAMA M. and LEFER D.J.: Endothelial nitric oxide synthase overexpression attenuates myocardial reperfusion injury. Am. J. Physiol. Heart. Circ. Physiol., 286: 276 -282, 2004.

27- WU L., FANG J., CHEN L., ZHAO Z., LUO Y., and LIN C.: Low serum adropin is associated with coronary atherosclerosis in type 2 diabetic and non-diabetic patients. Clin. Chem. Lab. Med., 52 (5): 751-758, 2014.

28- DEMIRCELIK B., KURTUL A., OCEK H., CAKMAK M., CETIN M., and UREYEN C.: The Relationship between Adropin Levels and the Slow Coronary Flow Phenomenon. Ind. J. Clin. Biochem., 30 (4): 412-417, 2015.

29- KATHIR K. and ADAMS M.R.: Endothelial dysfunction as a predictor of acute coronary syndromes. Semin. Vasc. Med., 3 (4): 355-362, 2003.

30- AYDIN S., KULOGLU T., KALAYCI M., YILMAZ M. and CAKMAK T. : A comprehensive immunohistochemical examination of the distribution of the fat-burning protein irisin inbiological tissues. Peptides, 61: 130-136, 2014 


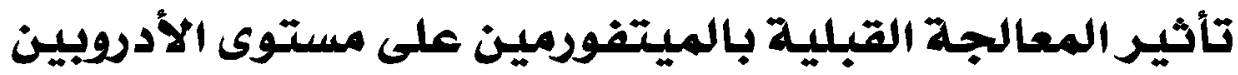

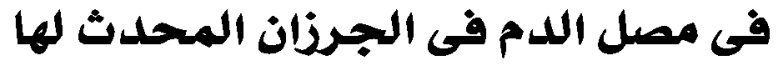 أحتشاء لعضلة القلب بول الجراسطة الأدرينالين}

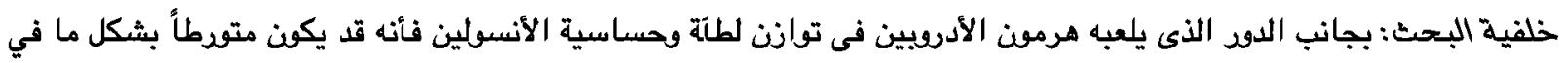

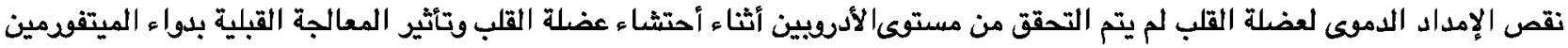

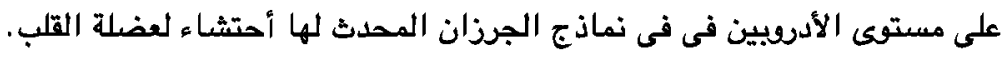

الهدف من العمل: هو دراسة مستوى الأدروبين فى حالات أحتشاء عضلة القلب وأحتمالية مشاركة الأدروبين والإنزيم المصنع

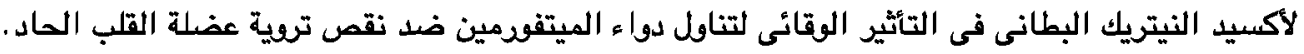

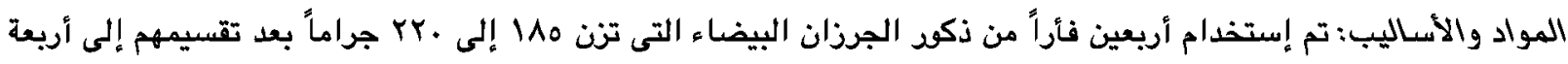
مجموعات متساوية العدد (عشرة جرزان لكل منها ). - المجموعة الأولى: المجموعة الضعابطة الطبيعية.

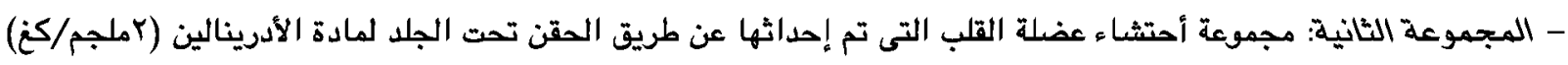
فى جرعتين تفصل بينهما فترة ع ب ساعة.

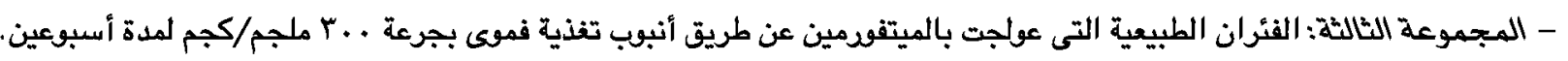

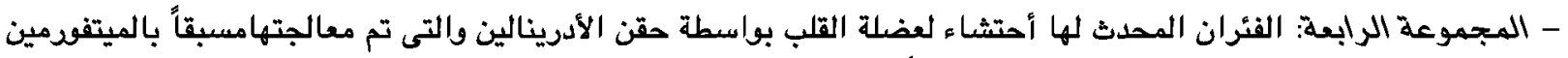

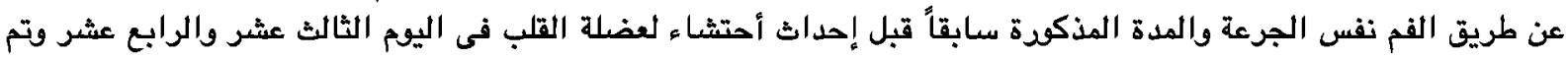

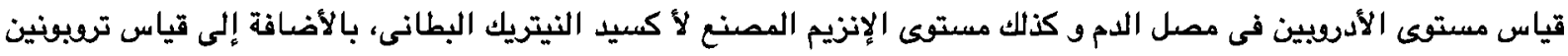

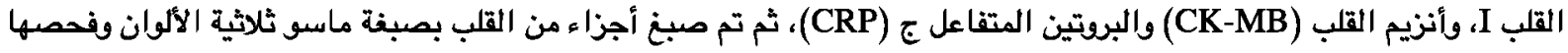

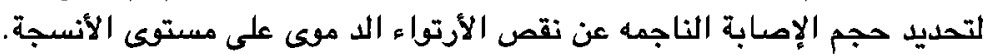

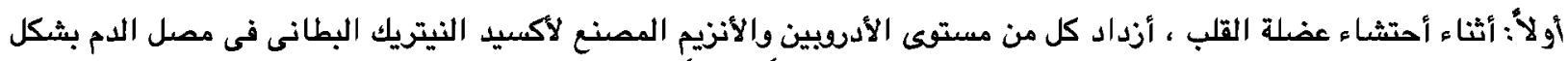

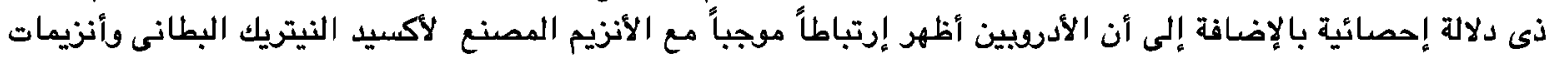
القلب دK-MB Troponin I دلا ثانياً: أنتجت المعالجة القبلية بالميتفومين فى المجموعة الرابعة بعض الإنخفاض فى المستوى المرتفع من الأدروبين وذيادة مستطرد

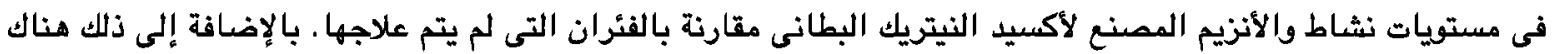

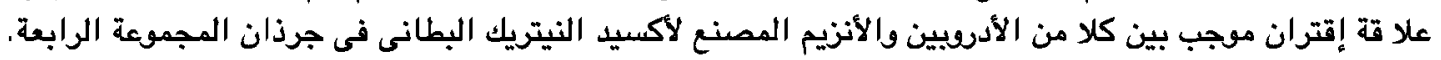

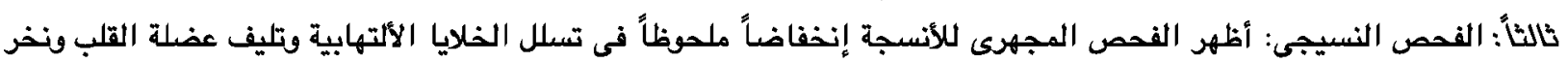
أليافها.

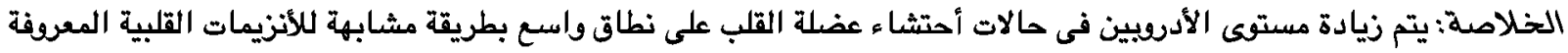

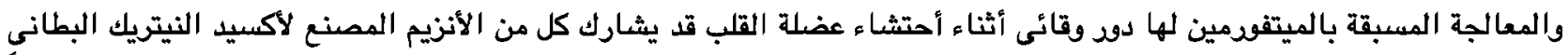

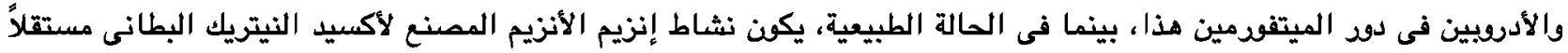
عن مستوى الأدروبين هو الآلية المحتملة. 